(CAPA Journals; This article may not exactly replicate the authoritative document published in the APA journal. It is not the copy of record

\title{
Outgoing Editorial
}

\section{Penny M. Pexman}

This first issue of 2018 marks the beginning of a year of Editorial transition at the Canadian Journal of Experimental Psychology (CJEP). I will continue to handle any manuscripts in our editorial system, or in revision, as of December 31, 2017. Incoming Editor Randall Jamieson will handle all new submissions that arrive after that date.

CJEP quietly turned 70 in 2017, and 2018 marks 25 years since the Journal's name was modified from Canadian Journal of Psychology to the Canadian Journal of Experimental Psychology, during Colin MacLeod's Editorship. Through this and other changes, our mission has remained the same. As Colin stated in the abstract to his editorial announcing the name change, our goal is: "to publish the best new research in experimental psychology, both Canadian and international, in both French and English" (1993, p. i). We are a Canadian journal, supported by a strong community of Canadian researchers and organizations, but the science shared on our pages is as broad and international as experimental psychology itself.

I have continued many of the traditions of previous editors; for instance, publishing about one special issue a year assembled by outstanding guest editors. This has included special sections on Embodied Cognition (June, 2015, Stephen J. Lupker, Guest Editor) and Numerical Cognition (March, 2016, Jamie Campbell, Guest Editor), and special issues on Immediate Memory (March, 2015, Aimée Surprenant, Jean Saint-Aubin \& Ian Neath, Guest 
Editors), the Production Effect in Memory (June, 2016, Glen Bodner \& Colin MacLeod, Guest Editors), and Everyday Attention (June and September, 2017, Evan Risko \& Alan Kingstone, Guest Editors). These issues have attracted high quality submissions on topics that are important to our discipline.

I have also made some changes, to try to anticipate and respond to shifts in psychological research and in the ways that we share it. Perhaps most importantly, in 2017 CJEP became part of a pilot project of APA Journals to offer Open Science Framework badges. The badges acknowledge papers that meet standards for openness of data, methods, or research process. Steve Lindsay, current Editor of Psychological Science, was a key source of information about this initiative, and Annie Hill at APA Journals provided great support. Applying for badges is voluntary for CJEP authors, and our hope is that the badges will provide mechanisms for good practice. We have also added public significance statements to articles published in CJEP. These short summaries use everyday language to describe the goals and findings of published papers. By making their data, materials, or research plans publicly available, and by describing it in plain terms, CJEP authors help to improve the transparency and accessibility of our science.

A highlight of my Editorship has been getting to work with the great people who support our activities, at the Canadian Psychological Association (especially our Managing Editor, Lisa Votta-Bleeker), APA Journals, and the Canadian Society for Brain, Behaviour and Cognitive Science. I am grateful to my insightful and responsive Editorial Board members, who all agreed to stay on when my initial three-year term was extended to five. I am particularly grateful to my two brilliant Associate Editors, Randall Jamieson and Isabelle 
Blanchette. They have given a huge amount of time to their roles, and I have regularly been inspired by their thoughtful, constructive decisions about manuscripts submitted to CJEP.

Winding down my term as CJEP Editor is bittersweet. It has been time-consuming, certainly, but I have been proud to be the Editor of CJEP; proud, too, to be its first female Editor and hopeful that it won't be long before we have another. I was able to take on this role in large part because of the support of the generous colleagues who encouraged and nominated me, the workload considerations provided by my Department and my Dean, and by the endless good humour of my partner, Dave Pexman, who would sometimes find me doing editorial work in the early hours and ask "So, how many dreams have you crushed this morning?" Of course, I won't be leaving the journal behind. I've joined Randy's Editorial Board and look forward to supporting the incoming Editorial team and the future success of CJEP.

\section{Reference}

MacLeod, C. M. (1993). Editorial. Canadian Journal of Experimental Psychology/Revue canadienne de psychologie expérimentale, 47 , i-ii. 